\title{
Manifestations and Causes of Civil Service Corruption in Developing Countries
}

\author{
Yemane Desta \\ Department of Public Administration, \\ University of Asmara, Eritrea
}

Received: June 16, 2019 Accepted: July 11, 2019 Online published: July 28, 2019

doi:10.5296/jpag.v9i3.14930 URL: https://doi.org/10.5296/jpag.v9i3.14930

\begin{abstract}
This article examines the manifestations and causes of civil service corrupt practices in the context of developing countries based on review of theoretical and empirical literature regarding corruptiion in the context of developing countries. The article identified the most common forms of corruption including bribery, embezzlement, fraud, extortion, abuse of power, conflict of interest, insider trading/abuse of privileged information, favoritism, collusion with business interests, procurement contract/bid rigging and influence peddling. The findings of the study indicate that the main drivers of civil service corruption in developing countries are politicization of the civil service, poor pay, lack of accountability/transparency in public organizations, weak enforcements mechanisms, lack of merit-based career advancement, and excessive/ opaque regulations. The findings reported this article reveal that corruption in the civil service and overall corruption levels in politics, economy, and society are very high, with the negative outcome of hampering economic growth, sabotaging social justice and contributing to political instability.
\end{abstract}

Keywords: accountability, civil service, corruption, developing countries

\section{Introduction}

Corruption, broadly defined as the abuse of public office for private gain by the World- Bank, has been acknowledged as a universal problem. (World Bank,1997). Corruption which constitutes ethical violation on the part of public officials including the elected (politicians) and appointed (civil servants) poses a serious challenge to public trust. According to Makinda and Nduku (2014) corruption is a global phenomenon, cutting across faiths, religious denominations and political systems. It is ever-present in all governments and is found in democratic and dictatorial systems, feudal, capitalist and socialist economies. However, we can safely argue that developing countries already suffering from poverty, poor health, high levels of illiteracy, low economic growth, and political instability would be much more prone 
to corruption and more seriously harmed by it than the developed countries. Corruption has tendency to exacerbate and cause conflicts, promote poverty, and impact negatively on the best use of human and natural resources. (Aloko and Abdullahi, 2018).

Corruption in more widespread and has greater debilitating consequences in poor countries than in rich countries. Corruption has become a challenge to the governments and societies in different parts of the world; it eats the wealth of peoples, hinders investment and weakens the rule of law besides undermining the legitimacy of government, democratic values, human rights and respect for the rule of law. (Makinda \& Nduku, 2014) According to one official of the Word Bank corruption has been dubbed as the "AIDs of democracy" for developing countries.

Quoted by Thompson (2013) in his foreword to the United Nations Convention Against Corruption (UNCAC) in 2003, the then UN Secretary-General Kofi Annan said that:

Corruption is an insidious plague that has a wide range of corrosive effects on societies. It undermines democracy and the rule of law, leads to violations of human rights, distorts markets, erodes the quality of human life, and allows organized crime, terrorism and other threats to human security to flourish. This evil phenomenon is found in all countries - big and small, rich and poor - but it is in the developing world that its effects are most destructive. Corruption hurts the poor disproportionately by diverting funds intended for development, undermining a Government's ability to provide basic services, feeding inequality and injustice and discouraging foreign aid and investment. Corruption is a key element in economic underperformance and a major obstacle to poverty alleviation and development.

The existence of widespread corruption, especially in developing countries beset by mass poverty and very high levels of unemployment, has a deeply corrosive effect on trust in government and contributes to economic stagnation, crime and political disorder. Moreover, curbing corruption is exceedingly complex because it is not practiced by trespassers and outsiders, rather it is often institutionalized within government agencies that ensure that corrupt activities are continued and reinforced. Individuals with good intentions cannot easily revoke the system. (Asea, 2018) Understanding the forms of corruption and its root causes in the context of developing countries can be the starting point for the country-specific design and implementation of anticorruption reforms.

\section{Nature of Corruption}

The most widely used definition of corruption is provided by the World Bank. According to the World Bank corruption is defined as "as the abuse of power for private gain" (World Bank, 1997). The World Bank elaborates more clearly by stating that:

Corruption involves behavior on the part of officials in the public and private sectors in which they [public and private officials] improperly and unlawfully enrich themselves and/or those close to them, or induce others to do so, by 
misusing the position in which they are placed

This definition covers various forms of interaction between public sector officials and other agents. Sometimes, money is involved, such as in bribery or kickbacks for public procurement contracts. In other cases, private gain can be non-monetary, as in cases of patronage or nepotism. (Kolstad et al, 2008) A distinction is made between political corruption and administrative corruption. In the former politicians manipulate the instruments of the state for their own personal benefit, and thus terribly distort policy, to the point they effectively 'own' the state and its institutions and resources. (Gaycar, 2015). While the latter refers to corruption committed by bureaucrats, especially street level bureaucrats. (Suleiman \& Othman, 2017).

Empirical research to measure corruption is quite a new undertaking that only began in earnest in 1993 with the establishment of Transparency International, a civil society organization dedicated to curbing both international and national corruption and the widespread application of corruption indices developed by Transparency International (TI). The Corruption Perception Index (CPI) which was introduced in 1995 is a composite index, drawing on 16 surveys from 8 independent institutions. The surveys embrace the perceptions of business people, the general public and country analysts. The Corruption Perception Index (CPI) ranks countries in terms of the degree to which corruption is perceived to exist among public officials and politicians.

The Berlin-based Transparency International annually develops the global CPI based on a score of zero to 100 (zero being highly "corrupt" and 100 being highly "clean") The 2018 CPI depicts a disturbing picture about the pervasiveness of corruption in the world and especially in developing countries:

- Two out of three countries score less than 50 out of a clean score of 100 in the CPI 2018, which reflects perceived level of corruption among politicians and public officials in 120 countries.

- Nine out of ten developing countries scored less than 50 against a clean score of 100 in the CPI 2018.

- Five out of ten developing countries scored less than 30 out of 100, indicating a high level of corruption

- The bottom ten countries perceived to be most corrupt are all developing countries

Corruption is perceived to be pervasive Somalia, South Sudan, Syria, Afghanistan, Yemen, Sudan, Libya, Guinea Bissau, Equatorial Guinea, North Korea, Venezuela, and Iraq with a score of less than 20 in the current index. (Transparency International, 2018) Denmark and New Zealand top the index with 88 and 87 points respectively. Somalia and South Sudan and Syria are at the bottom of index, with 10, 13 and 13 points, respectively. The highest scoring region is Western Europe, with an average score of 66, while the lowest scoring region is Sub-Saharan Africa with an average score of 32. 
Table 1. A Partial Profile of Corruption Around the World (2018 rankings)

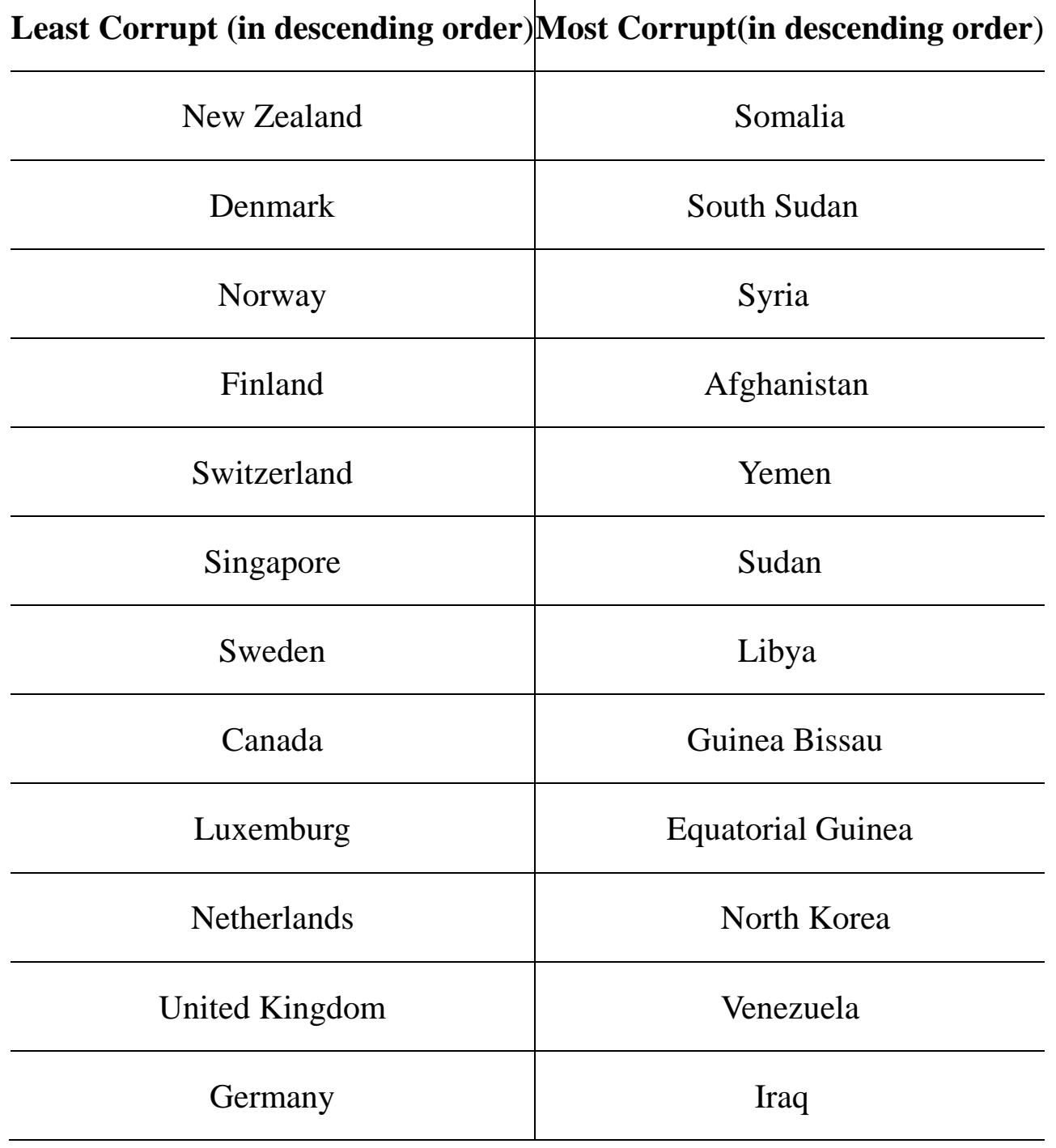

Source: (Transparency International, 2018)

\section{Manifestations Corruption in the Civil Service of Developing Countries}

Corruption in the civil service encompasses government officials' behaviors and actions that involve lack of accountability, unethical behavior and corrupt behavior. Corrupt practices include bribery, patronage, nepotism, embezzlement, influence peddling, use of one's public position for self-enrichment, bestowing of favors on relatives and friends, moonlighting, partiality, absenteeism, late coming to work, abuse of public property, leaking and/or abuse of government information and the like. (Sedigh \& Ruzindana, 2004)

The typical manifestations of corruption in the civil service in developing countries include: 


\subsection{Bribery}

Bribery involves the promise, offering or giving of a benefit that improperly affects the actions or decisions of a public servant. Bribery is widely considered as the commonest type of corruption. (Otusanya, 2011). Poor countries tend to have the highest levels poverty and the poor, who depend the most heavily on public services, often, face demands for bribes to obtain them. (Warf, 2017) In the some of the developing where bribery is widespread and endemic, it is often accepted simply as another part of doing business. Bribery may be viewed simply as a means to get the bureaucratic machinery to move forward, and enriching oneself at public expense may not be seen as particularly loathsome. (Warf, 2017) According Mynit (2000) bribes operate in a number of ways:

- Bribes can influence who gets the contract, the terms of the contract, as well as terms of subcontracts when the project is implemented

- Bribes can influence the allocation of monetary benefits such as credit subsidies and favored prices and exchange

- Bribes can be used to reduce the amount of taxes, fees, dues, custom duties, and electricity and other public utility charges collected from business firms and private individuals.

- Bribes can speed up the granting of permission, licenses and permits to carry out activities that are perfectly legal. This is the so-called "grease money".

\subsection{Extortion}

Extortion involves coercing a person or entity to provide a benefit to a public servant (s) in exchange for acting (or failing to act) in a particular manner. It is similar to bribery only that the money is extracted using violence or threat of violence to extract money. (Varga-Hernandez, 2012) Whereas bribery is voluntarily offered by a citizen to public official, extortion is considered involuntary as the bribe-giver is offering bribe to avoid the wrath of overbearing and rent-seeking public official. (Okochukwu, 2002)

\subsection{Embezzlement}

Embezzlement involves theft of public resources, monetary or otherwise, by public servants entrusted with the authority and control of such resources. As an effect of embezzlement plundering of public resource is taking place. Embezzlement is characterized by the taking or conversion of money, property or other valuables for personal befits from the coffers of the government. (Varga-Hernandez, 2012)

\subsection{Fraud}

Fraud involves actions or behaviors by a public servant (s) that misleads other persons or entities (government, NGOs, or private business) into providing benefit that would not normally accrue to the public servant (s). Fraud is considered as an economic crime that involves some kind of deceit for the purpose of individual or group enrichment. 


\subsection{Abuse of Power}

Abuse of power involves a public servant using his/her vested authority to improperly benefit another public servant, person or entity. It also can involve a public servant using his/her vested authority to discriminate against other public servants, persons or entities. Thus abuse of power involves the practice misusing discretion for personal gain without external inducement or extortion. The administrative structure functioning from high national levels to the local levels is established by corrupt government premised on enabling government bureaucrats to comprehensively abuse citizen rights for their own personal benefits and in complicity that of their partners and extended network. (Varga-Hernandez, 2012)

\subsection{Conflict of Interest}

Conflict of interest cases involve situations where a public servants acting or failing to act on a matter where the personal interest of the public servant or the interest of persons or entities related to the concerned official is directly or indirectly affected.

\subsection{Insider Trading/Abuse of Privileged Information}

Insider trading/abuse of privileged Information involves the use of privileged information or knowledge that a public servant possesses by virtue of occupying a public office to advance his/her interests of the interest of persons or entities related to the official. The abuse of privileged information for private gain is evidenced by the leaking of civil service examination papers, school examination papers, classifies government documents, and terms of contracts in advance of competitive bidding for government contracts. (Zafrullah and Siddiquee, 2001)

\subsection{Favoritism}

According Suleiman \& Othman (2017) favoritism denotes bestowal of preferential treatment or favor by an entrusted office holder on the basis of prejudices such as family relationship, ethnic, party or religious affiliation, or even friendship. Cronyism, nepotism and patronage-favors and opportunities bestowed on friends, family and supporters without regard to qualifications, individually or in combination, are the core to corrupt practices (Caiden, 2001) In this aspect favoritism is considered as broader concept than nepotism. Favoritism in the civil service involves the sale of official's posts, positions, or promotion; nepotism; or other actions that undermine the creation of professional, meritocratic civil service. Favoritism also known as cronyism entails to grant offices or benefits to friends regardless of their abilities. A special form of favoritism is nepotism. Nepotism means that an office holder will favor his/her relatives and family members. Another instance of favoritism is cronyism which involves bestowing benefits and privileges to one's friends and acquaintances.

\subsection{Collusion with Business Interests}

Collusion involves payments to government officials to foster or to sustain monopolistic or oligopolistic access to markets in the absence of compelling economic rationale for such restrictions. Corruption can be collusive in nature where individuals escape official 
regulations or sanctions by paying payments to government officials. (Varga-Hernandez, 2012)

\subsection{Obstruction of Justice}

Obstruction of justice occurs when the natural process of justice or fairness is subverted to the benefit of few wealthy, well-connected, and powerful individual and groups to the detriment of the wider public. The selective application of laws would be a case in point. In most developing countries the people who are rich and well-connected to powerful government officials do not face justice or penalty for serious infarctions of the law.

\subsection{Procurement Contract/Bid Rigging}

Procurement contract/bid rigging includes procurement fraud, including collusion, overcharging, or the selection of contractors, suppliers, and consultants other than the criteria other than the lowest evaluated substantially responsive bidder. Project related corruption permeates both public and private sector contracting. A substantial commission must be paid to secure large public sector contracts.

\subsection{Influence Peddling}

Influence peddling popularly known as trading in influence refers to a situation where a person misuses his/her influence over the decision making process for a third party (person, institution or government) in return for his/her loyalty, money or any other material or immaterial undue advantage. (Slingerland, 2010) Thus when civil servants engage in influence peddling they unlawfully or illegally using their influence over the decision making process with the intention of benefiting a third party. (Slingerland, 2010) The natural expectation is that the benefiting third party would reward the government bureaucrats with money, wealth or any advantage.

The corrupt practices identified range from common bribery by field level civil servants to grand theft orchestrated through collusion among politicians, bureaucrats, and crooked businessmen. The above discussion on the manifestations corruption in the civil service by no means is an exhaustive one as the corrupt practices and administrative malfeasance that occur in the public domain take numerous forms with differing degrees of intensity.

\section{Causes of Civil Service Corruption in Developing Countries}

According Kaufmann (2000) developing countries are more prone to be affected by corruption for a variety of reasons, including:

- the widespread poverty and low level of public sector salaries

- lack of any risk spreading mechanisms such as insurance and a well-developed market

- opportunities presented by complex, poorly-defined, constantly changing and inadequate rules and regulations 
- lack of properly established laws and principles, or code of conduct applicable to public officials and lack of institutions to enforce them

- lack of watch-dog agencies

In Sub-Saharan Africa, some of the identifiable causes of corruption include the negative colonial legacy, poor leadership, politics of the belly, omnipotent state, greed and selfishness, clientelism and patronage nepotism, absence of popular participation of the public in government, weak institutions of governance, lack of accountability and transparency, lack of political will, weak ethical values, centralist nature of the state and concentration of state power, weak judicial system and constant insecurity and conflicts. (Loch and Lumumba, 2014) In the case Asian countries corruption has five major causes. (Quah, 2006). These factors include low salaries of civil servants, the expansive role of governments (increased administrative discretion), low risk of detection and punishment, the primacy of the family and Asian traditions of gift giving, and lack of political will to combat corruption. The supremacy of ethnic identity over national identity has also been blamed as a driver of corruption in in the majority of developing countries where national interest has been fractures due to tribal loyalties. Traditional societies are largely characterized by competing loyalties and sub national identities; for instance African populations are often just as much in conflict with each other as rival African politicians. (Ganahl, 2013) Corruption in developing countries is not a problem that is caused and sustained by internal factors alone. Rather, it is also a consequence of external factors manifested through the activities of foreign government, private corporations, and aid organizations seeking to further their interests (economic and strategic) through actions that condone corrupt practices or that are corrupt in themselves. (Mullinge \& Lesetedi, 2002). In sum corruption in developing countries has been fueled by a complex set of political, economic, social and psychological factors.

Although the drivers of corruption are numerous, the most common causes of civil service corruption in the context of developing countries identified in this article include:

\subsection{Politicization of the Civil Service}

When civil service positions are used as rewards for political support or swapped for bribes, or used to meet obligations to one's ethnic cleavage the opportunities for high levels of corruption increase significantly. (Mbaku, 1997) According to Okochuwu (2002) in most developing countries civil service job appointments often depend on factors that have nothing to do with qualifications or competence. Instead, appointments are based on party loyalty, friendship, and cronyism. The net result of having a highly politicized civil service is among other things producing unethical civil servants who are prepared sacrifice the interest of public to please their political masters.

\subsection{Poor Remuneration and Compressed Salary Scales}

Corruption in Nigeria and other developing countries in part can been explained in terms of low public pay. Public officials in developing countries are corrupt because their salaries are so low that they cannot make ends meet by depending solely on their meager earnings. (Obuah, 2010). The problem of low pay is in the civil service is accompanied by the 
compression of salary scale, or in adequate differentials between the highest and lowest grades. In the face of perceived internal (in relation to their junior colleagues) and external equity (in relation to their counterpart in the private/NGO sector) higher-level civil servants in the civil service may be tempted to augment their pay illicit means in a bid to meet their needs. Mbaku (1996) argues that the African extended family places a significant pressure on the government bureaucrat forcing him to engage in corruption.

\subsection{Problem of Career Advancement within the Civil Service}

The highly hierarchical and rigid structure of the civil service is a factor contributing to the administration corruption existing in the government bureaucracy. The very rigid career paths available for the more competent civil servants mean that they cannot make progress past long-serving civil servants who are sitting in their positions on the sole basis of seniority with out link to performance on the job. For instance Habib Zafrullah et al. (2000) state that the promotion system in the civil service of Bangladesh is aberrant and overwhelmingly in favor of the incompetent and the inefficient.

\subsection{Lack Accountability in Public Organizations}

The very low quality of accountability in government stems from two main important sources: the legacy of colonialism and lack of fully-fledged democratic system. (Padam, 1999) The post independence governmental bureaucracy that emerged in most countries contributed to institutional instability, the politicization of the state, and patrimonial economic management and incentives, whereby political and personal loyalty and obedience were rewarded more than merit. ((Dia, 1996 cited in Hope, 1997). With no effective restraints on government behavior, corruption became widespread, and favoritism and cronyism undermined the very substance and neutrality of public power by failing, among other things, to satisfy the civic requirement for public accountability and integrity. (Hope, 1997). Mbaku (1998) asserts that in the case of post-colonial Africa the capture of governance systems by indigenous elites instead of increasing the welfare of the previously marginalized people has resulted in the manipulation of state power by the ruling elites to plunder the economy for their own benefit.

\subsection{Weak Institutions for Enforcing Ethical and Accountability Standards}

Corruption is principally a governance issue - a failure of institutions and a lack of capacity to manage society by means of a framework of social, judicial, political and economic checks and balances. (Mbaku,1998). When these formal and informal systems break down, it becomes harder to implement and enforce laws and policies that ensure accountability and transparency.

\subsection{Excessive and Opaque Regulations}

A fertile ground for growth of a thoroughly corrupt system will emerge in a country if it has a large number of laws, rules, regulations, and administrative orders to restrict business and economic activities and thereby creates huge opportunities for generating economic rent, and especially if these restrictive measures are complex and opaque and applied in a selective, secretive, inconsistent and non-transparent way. (Mynit, 2000) Public officials may raise a 
firm's costs by introducing delays and unnecessary requirements as a way of inducing payoffs, for instance, in contracting and auctioning or in administering regulatory and tax laws. (Rose-Ackerman, 1999) In many countries, and especially in developing countries, the role of the state is often carried out through the use of numerous rules or regulations. The existence of numerous the regulations where some of them are nontransparent or are not even publicly available and that an authorization can be obtained only from a specific office or individual-that is, there is no competition in the granting of these authorizations - gives the bureaucrats a great amount of power and a good opportunity to extract bribes. (Tanzi, 1998)

The discussion on the multifaceted nature of the causes of corruption in the government bureaucracy clearly reveals that the fight against corruption has to take a holistic, integrated approach. The challenge before the government and the public in developing countries is to conduct a vigorous debate on the multiple dimensions and causes of civil service corruption with the aim of discovering objective basis for formulating policies for enhancing public integrity and fighting corruption.

\section{Conclusion}

The findings reported in this article reveal civil service corrupt practices and overall corruption levels in politics, economy, and society are very high in the developing countries, with the obvious outcome of hampering economic growth, sabotaging social justice and contributing to political instability. Corruption is not the exclusive domain of developing countries, yet its damaging effects are strongly felt by those countries already in the grip of economic underdevelopment, political instability, and social injustice. Among the developing regions Sub-Saharan Africa has ranked consistently below the global score on the Transparency International Corruption Perception Index (CPI).

The article identified and described the corrupt practices ranging from common bribery by field level civil servants to grand theft orchestrated through collusion among politicians, bureaucrats, and crooked businessmen. These corrupt practices include bribery, embezzlement, fraud, extortion, abuse of power, conflict of interest, insider trading/abuse of privileged information, favoritism, collusion with business interests, and procurement contract/bid rigging and influence peddling.

The review of the evidence examined indicates that politicization of the civil service, low public sector salaries, lack of accountability, weak enforcement mechanisms, and excessive regulatory procedures are consistently mentioned in the corruption surveys as the underlying factors that fuel corruption in the civil service in the context of developing countries. Country-specific diagnostic studies are needed to pinpoint the root causes of civil service corruption pertaining to a given developing country. Country wide surveys of the opinions of public officials, households and business people would be critical for discovering the causes and eventual remedies for corruption in the public sector. 


\section{References}

Aloko, S., \& Abdullahi, U. (2018). Corruption and Underdevelopment in Nigeria: Challenges and Solutions. Scientific Research Journal (SCIRJ), 6(7), 1-10

Asea, W. (2018). Combating political and bureaucratic corruption in Uganda: Colossal Challenges for the Church and the Citizens. Theological Studies, 74(2), 72-80.

https://doi.org/10.4102/hts.v74i2.4535

Caiden, G. E. (2001). Where corruption lives. Kumarian Press. Boulder, Colorado.

Forson, J., Yaaba, B. E., Ponlapat, T. B., Chen, G., \& Peng, Z. (2016). Causes of Corruption: Evidence from Sub-Saharan Africa. South African Journal of Economic and Management Sciences, 19(4), 562-557. https://doi.org/10.4102/sajems.v19i4.1530

Ganahl, J. (2013). Corruption, Good Governance, and the African State: A Critical Analysis of the Political-Economic Foundations of Corruption in Sub-Saharan Africa. Potsdam University Press. Potsdam, Germany.

Gong, T., \& Wu, A. (2012). Does Increased Civil Service Pay Deter Corruption? Evidence from China. Review of Public Personnel Administration, 32(2), 192 -204.

https://doi.org/10.1177/0734371X12438247

Graycar, A. (2015). Corruption: Classification and Analysis. Policy and Sociey, 34, 87-96. http://dx.doi.org/10.1016/j.polsoc.2015.04.001

Habib, Z., \& Noore, S. (2001). Dissecting Public Sector Corruption: Issues and Problems of Control. Journal of Public Organization Review, 1(4), 465-486.

https://doi.org/10.1023/A:1013740000213

Hope, K. R. Sr. (1997). African Political Economy: Contemporary Issues in Development, Armonk, NY; M. E. Sharpe.

Kaufmann, D. (2000). Governance Matters: From Measurement to Action. Finance and Development, 37(2).

Kupendeh, S. J. (1995). Politics and Corruption in Africa: A Case Study of Sierra Leone. Lanham: University Press of America.

Loch, P., \& Lumumba, O. (2014). Corruption: The Bane of Africa. In Nduku Elizabeth \& Tenamwenye John (Eds.), Corruption in Africa: A Threat Justice and Sustainable Peace, 17-46. Globethics.net International Secretariat: Geneva Switzerland.

Obuah, E. (2010). Combating Corruption in A failed State: The Nigerian Economic and Financial Crimes Commission. Journal of Sustainable Development in Africa, 12(1), 27-52.

Oko, O. (2002). Subverting the scourge of Corruption in Nigeria: A Reform Prospectus . International Law and Politics, 36. 


\section{Mll Macrothink}

Journal of Public Administration and Governance ISSN 2161-7104 2019, Vol. 9, No. 3

Otusanya, O. J. (2011). Corruption as an Obstacle to Development in Developing countries: A Review of Literature. Journal of Money Laundering Control, 14(4), 387-422. https://doi.org/10.1108/13685201111173857

Makinda, E., \& Nduku, H. (2014). Combatting Corruption in Society: A Challenge to Higher Education in Africa. In Nduku Elizabeth \& Tenamwenye John (Eds.), Corruption in Africa: A Threat Justice and Sustainable Peace, 281-301. Globethics.net International Secretariat: Geneva Switzerland.

Mbaku, J. (1996). Bureaucratic Corruption in Africa: The Futility of Cleanups. The Cato Journal, 16(1), 1-17.

Mbaku, J. (1998). Institutions and Reform in Africa: The Public Choice Perspective. Westport, CT: Praeger Publishers.

Mullinge, M., \& Lesetedi, G. (2002). Corruption in Sub-Saharan Africa: Towards a More Holistic Approach. African Journal of Political Science, 7(1), 51-77.

https://doi.org/10.4314/ajps.v7i1.27324

Myinit, U. (2000). Corruption and Income Distribution. Asia-pacific Development Journal $7(2)$.

Kolstad, I., Fritz, V., \& O’Neil, T. (2008). Corruption, Anti-corruption Efforts and Aid: Do Donors Have the Right Approach? Working Paper 1. Research Project for Advisory Board for Irish Aid. Overseas Development Institute. London. [online] Available:

https://www.odi.org/publications/1525-corruption-anti-corruption-efforts-and-aid-do-donorshave-right-approach

Paldam, M. (1999). The Cross-country Pattern of Corruption: Economics, Culture and Society Dynamics, Working Paper No 11, Department of Economics, University of Aarhus, Denmark. [online] Available:

http://www.martin.paldam.dk/Papers/Gamle/Culture\&Corruption.pdf

Quah, J. (1999). Corruption in Asian Countries: Can it be Minimized? Public Administration Review, 59(6), 483-494. https://doi.org/10.2307/3110297

Rose-Ackerman, S. (1999). Corruption and Government: Causes, Consequences, and Reform. Cambridge, U.K.: Cambridge University Press. https://doi.org/10.1017/CBO9781139175098

Sedigh, S., \& Augustine, R. (1999). The fight against Corruption in Uganda. In Rick Stepenhurst and Sahr (Eds.), Curbing Corruption. Washington D.C, Economic Development Institute of the World Bank.

Slinegerland, W. (2010). Trading in Influence: Corruption Revisited. Paper presented at the Ethics and Integrity of Governance, Toulouse, France 8-10 September. [online] Available: https://www.law.kuleuven.be/integriteit/egpa/egpa2010/slingerland_trading-in-influence.pdf

Suleiman, N., \& Othman, Z. (2017). Corruption Typology: A Review of Typology. Chinese Business Review, 16(2). 102-108. 
Tanzi, V. (1998). Corruption Around the World: Causes, Consequences, Scope, and Cures. IMF Staff Papers, 45(4), December. https://doi.org/10.2307/3867585

Transparency International. (2014). Corruption Perception Index(CPI) 2014. Berlin Germany. [online] Available: www.transparency.org/cpi

Transparency International. (2018). Corruption Perception Index(CPI) 2018. Berlin Germany. [online] Available: www.transparency.org/cpi

Vargas-Hernández, J. (2012). The Multiple Faces of Corruption: Typology, Forms and Levels. Department of Administration, University Center for Economic and Managerial Sciences University of Guadalajara, Mexico. [online] Available:

https://pdfs.semanticscholar.org/fb6e/bcf3520c6f7904c588c495b2fcdd6b2577a9.pdf

Warf, B. (2017). Geographies of African Corruption. PSU Research Review, 1(1), 20-38. https://doi.org/10.1108/PRR-12-2016-0012

World Bank. (1997). 'Corruption Definition', [online] Available http://www.anticorruption.info/corr_def_alt.htm

\section{Copyright Disclaimer}

Copyright for this article is retained by the author(s), with first publication rights granted to the journal.

This is an open-access article distributed under the terms and conditions of the Creative Commons Attribution license (http://creativecommons.org/licenses/by/4.0/). 